\title{
Examination of gastroesophageal reflux by transabdominal ultrasound: Can a slow, trickling form of reflux be responsible for reflux esophagitis?
}

\author{
László Mádi-Szabó MD PhD, György Kocsis MD
}

L Mádi-Szabó, G Kocsis. Examination of gastroesophageal reflux by transabdominal ultrasound: Can a slow, trickling form of reflux be responsible for reflux esophagitis? Can J Gastroenterol 2000;14(7):588-592.

BACKGROUND: Ultrasound can visualize significant portions of the upper and lower esophagus; it is without any instrumental interference in real conditions and displays events in motion.

PURPOSE: To study the events that occur during swallowing and gastroesophageal reflux.

PATIENTS AND METHODS: Group 1 comprised 25 patients with retrosternal complaints, selected for esophageal surface ultrasonography for endoscopic signs of esophagitis. Group 2 comprised 25 patients who underwent initial transabdominal ultrasonography. For 3 to $6 \mathrm{~h}$ before ultrasonography, nothing was given by mouth to the 50 patients labelled as having gastroesophageal reflux disease (GERD). Ultrasonography was then performed for 15 to 20 mins after drinking one mouthful of water or tea, or swallowing some saliva to provoke reflux. The events were recorded on videotape rolls. Endoscopy was carried out in all 50 cases; in 46 cases ( 21 and 25 from groups 1 and 2, respectively), gastric acidity and bacteriology were subsequently examined (test meal). Manometry and $\mathrm{pH}$ were not measured to avoid provocation of reflux by the instruments. Thirty patients without any esophageal complaints or signs of esophagitis (though suffering from gastric and duodenal diseases) were designated as the control group (group 3). The available results were compared.

RESULTS: In 32 of 46 patients diagnosed with GERD (69.5\% in groups 1 and 2), a special kind of reflux was observed by ultrasonography: a slow, trickling reflux of the gastric content was seen, mostly after swallowing. A fast clearance followed four to six episodes of the trickling reflux, only after an interval of 0.5 to 2 mins. Only fast refluxes and immediate clearance were observed in the control group.

CONCLUSIONS: The observations above may indicate a special form of gastroesophageal reflux, namely, a slow, trickling form

continued on next page 
of it. It can be responsible for the development of GERD. Fast reflux and immediate clearance are common; however, this special trickling form was observed only in GERD patients. This may explain a number of often contradictory measurements and can make the effect of cisapride more understandable. A test meal is always necessary to distinguish a bilious reflux from an acidic one, because only the latter may require aggresive antacidic treatment.

Key Words: Gastroesophageal reflux disease; Surface ultrasonography; Trickling gastroesophageal reflux

\section{Examen du reflux gastro-œsophagien par échographie transabdominale : Un reflux sous forme de suintement serait-il la cause d'une œsophagite par reflux?}

CONTEXTE : L'échographie ultrasonique permet de visualiser des parties importantes de l'œsophage supérieur et inférieur; elle n'a pas d'interférence instrumentale en conditions réelles et elle montre les événements en mouvement.

BUT DE L'ÉTUDE : Étudier les événements qui surviennent pendant la déglutition et le reflux gastro-œsophagien.

PATIENTS ET MÉTHODES : Le groupe 1 comprenait 25 patients se plaignant de douleurs rétrosternales, sélectionnés pour subir une échographie de la surface de l'œsophage pour des signes endoscopiques d'œsophagite. Le groupe 2 comprenait 25 patients qui avaient initialement subi une échographie transabdominale. De trois à six heures avant l'échographie, les 50 patients classés comme « ayant un reflux gastro-œsophagien » (RGO) n'ont rien reçu par la bouche. On a ensuite procédé à l'échographie pendant 15 à 20 minutes après qu'ils ont avalé une grande gorgée d'eau ou de thé, ou de la salive, pour provoquer un reflux. Les événements ont été enregistrés sur bande-vidéo. La totalité de ces 50 patients ont subi une endoscopie. Dans 46 cas ( 21 et 25 respectivement des groupes 1 et 2 ), on a ensuite mesuré l'acidité gastrique puis, pratiqué un test bactériologique (repas d'épreuve). La manométrie œsophagienne et la pH-métrie n'ont pas été réalisées afin d'éviter la provocation instrumentale d'un reflux. Trente patients ne se plaignant pas de douleurs oesophagiennes ou n'accusant pas de signes d'œsophagite (bien qu'atteints d'affections gastriques et duodénales) ont été désignés comme groupe témoin (groupe 3). On a ensuite procédé à l'analyse des résultats disponibles.

RÉSULTATS : Chez 32 patients sur 46 diagnostiqués avec un RGO (69,5\% dans les groupes 1 et 2), l'échographie a révélé un reflux sous forme de suintement, c'est-à-dire lent, s'écoulant goutte à goutte du contenu gastrique, principalement après la déglutition. Une clairance rapide faisait suite à quatre à six épisodes de suintement, seulement après un intervalle de 0,5 à 2 minutes. On a seulement observé des reflux rapides et une clairance immédiate dans le groupe témoin.

CONCLUSIONS : Ces observations pourraient suggérer l'existence d'un reflux sous forme de suintement, et qui peut entraîner le développement d'un RGO. Le reflux rapide suivi d'une clairance immédiate est courant ; toutefois, cette forme particulière de suintement n'a été observée que chez les patients atteints de RGO. Ceci pourrait expliquer le nombre de mesures souvent contradictoires et permettre de mieux comprendre l'effet du cisapride. Un repas d'épreuve est indispensable pour distinguer le reflux biliaire du reflux acide parce que ce dernier est le seul qui exige un traitement énergique avec des anti-acides.
$\mathrm{G}$ astroesophageal reflux disease (GERD) is well delineated; however, clinically it is incompletely understood. Esophageal irritation is caused by the reflux of gastric contents into the esophagus. Gastric contents can be acidic or bilious. Radiography and scintigraphy can show the existence of reflux but not in a way that can be studied in detail. $\mathrm{pH}$ measurements mostly register marked acidic episodes and episodes with a plateau in the esophagus; manometric measurements display the changes of pressure gradients. These methods provide a variety of often contradictory data that are explained rather arbitrarily. None of these procedures is simple for the patients. The instrumental methods change the condition in site, thereby exerting nonphysiological effects, the first of which is nausea. Thus, we may have contaminated data of the events that may happen to the esophagus under normal circumstances. Ultrasonography is a technique used to display the motion and streaming patterns in the gastroesophageal area without affecting the subject's physiology. Ultrasonographic data were added to those provided by endoscopy.

\section{PATIENTS AND METHODS}

A method of surface esophageal ultrasonography was structured after examining a number of unselected people, and a 'first-attempt survey' (to set the method in gastroesophageal reflux) was completed. Twenty-five patients with endoscopic signs of esophagitis grades 1 to 3 (group 1) were examined by ultrasound. Endoscopy preceded ultrasonogra- phy. An unusual motion pattern of gastroesophageal reflux was observed in an additional 25 patients with retrosternal acidic burning, with a nocturnal peak; these patients were examined, first by ultrasound and then by endoscopy (group 2). Any patient with cardiac and/or thoracic-related complaints was excluded at the beginning of the survey. Thirty other patients without any complaints or signs of esophagitis but having superficial gastritis (19 patients) or gastroduodenal ulcer (11 patients) were examined for upper panendoscopy and comprised the control group (group 3). There were 17 men and eight women in group 1 , aged 26 to 48 years, and 15 men and 10 women in group 2 , aged 29 to 58 years. In group 3, 18 men and 12 women, aged 22 to 42 years were ranked. Ultrasonography was carried out on all patients in the supine position, after 3 to $6 \mathrm{~h}$ of fasting. The transducer was positioned 45 oblique, left from the xyphoid process. After the longest available portion of the lower part of the gastroesophageal junction was identified, each patient was asked to swallow a mouthful of water or tea, or saliva ('sham swallowing') during the examination in order to provoke motion in the site of interest. Then, an abdominal surface ultrasound examination was recorded for approximately 15 to 20 mins on video. A Toshiba 250A ultrasonograph (Variotrade Kft, Hungary) with a $3.75 \mathrm{MHz}$ convex probe and a Panasonic 6200 video recorder (Panasonic Kft, Budapest, Hungary) were used.

On the subsequent day, group 2 also underwent esophagogastroscopic examination. An Olympus GIFQ20 upper 


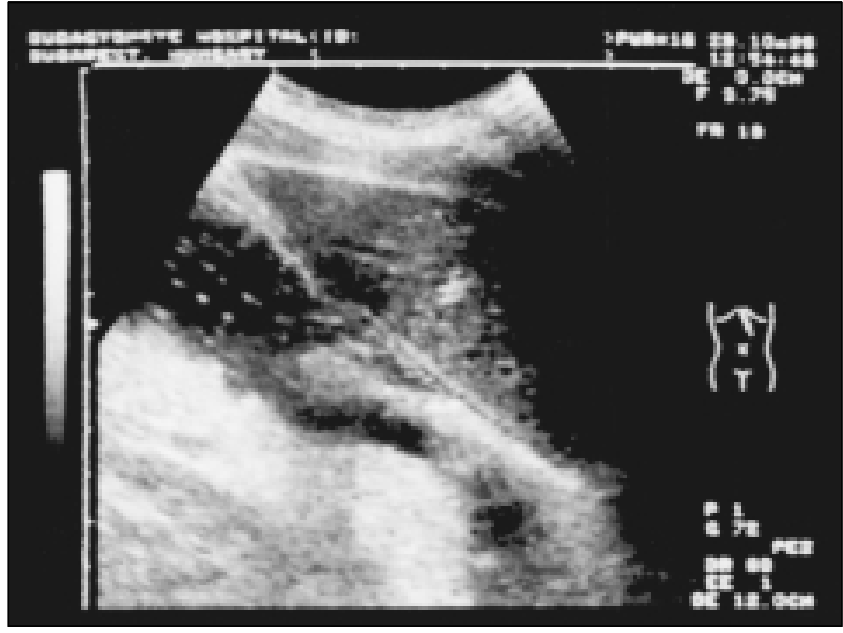

Figure 1) Longitudinal ultrasonogram of swallowing. Cranial to the right, caudal to the left. Note the discharge of the esophagus into the stomach

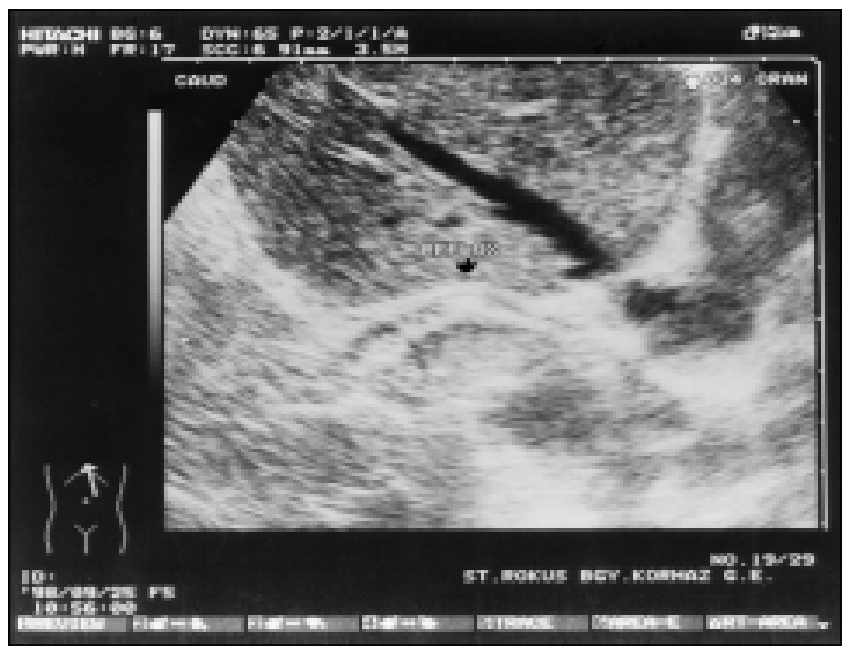

Figure 2) Longitudinal ultrasonogram of the lower portion of the esophagus and the cardia of the stomach. Cranial to the right, caudal to the left. Note a bubble trickling orally in the lower esophageal sphincter area

endoscope (Olympus Div Hungary, Hungary) with Sony video extension was used.

The following tests were carried out through a gastric tube in all 80 patients: $\mathrm{pH}$ and sodium hydroxide titration of acid, mucus and bilirubin indicated by crosses, benzidin, lactate measurements, bacterial cultivation and urease tests of the gastric contents. Biopsies were done in only 32 cases, for patchy mucosae or the suspicion of metaplasia (12 in group 1 and 20 in group 2). To prevent nonphysiological intrusions, no manometric or $\mathrm{pH}$ monitorings were used.

\section{RESULTS}

The dynamic events observed in real time abdominal ultrasonography cannot be displayed on a still photo, so only the ultrasonogram of a moment of the reflux in the gastroesophageal area (lower esophageal sphincter [LES],
TABLE 1

Data of 50 patients with gastroesphageal reflux disease

\begin{tabular}{lcccc}
\hline & $\begin{array}{c}\text { Acidic gastric } \\
\text { content }\end{array}$ & $\begin{array}{c}\text { Bilious } \\
\text { gastric } \\
\text { content }\end{array}$ & $\begin{array}{c}\text { Hernia } \\
\text { diaphragm }\end{array}$ & Esophagitis \\
\hline Group 1 $(n=25)$ & 23 & 2 & 10 & 25 \\
Group 2 $(n=25)$ & 18 & 7 & 8 & 21 \\
\hline
\end{tabular}

TABLE 2

The 'reflux-distribution' of $\mathbf{5 0}$ patients with gastroesphageal reflux disease (GERD) and 30 controls

\begin{tabular}{lcc}
\hline Cases & Ultrasound & Endoscopy \\
\hline $\begin{array}{c}\text { GERD found } \\
(\mathrm{n}=46)\end{array}$ & A 'trickling' form of reflux: & Esophagitis: 46 cases \\
& 32 cases $(69.5 \%)$ & $(100 \%)$ \\
$\begin{array}{c}\text { No GERD found } \\
(n=4)\end{array}$ & $\begin{array}{c}\text { Only fast reflux episodes: } \\
4 \text { cases }\end{array}$ & $\begin{array}{c}\text { Incompetent cardia: } \\
1 \text { case }\end{array}$ \\
$\begin{array}{c}\text { Control group } \\
(n=30)\end{array}$ & $\begin{array}{c}\text { No 'trickling', but some } \\
\text { fast reflux in all cases }\end{array}$ & $\begin{array}{c}\text { Normal esophagus: } 29 \\
\text { incompetent cardia: }\end{array}$ \\
& & 1 case \\
\hline
\end{tabular}

Figure 1) is shown. In the live events, after patients swallowed a mouthful, fast reflux of the gastric content was frequently seen immediately, and followed almost immediately by a fast clearing. In 32 people (of groups 1 and 2), however, another form was also observed - four to five episodes per minute of trickling, slow refluxes of the gastric content not followed by any aboral motoric activity of the esophagus (Figure 2). Clearance followed only after a number of trickling refluxes (in 0.5 to 2 mins) and was as fast as was seen in the 'fast form'. Additionally, the slow, trickling reflux stopped in some cases when the patient held his breath.

Preceeding or subsequent esophagogastroscopy revealed GERD, grades 1 to 3 (Barrett's esophagus in five), in 46 of 50 patients (92\%) in groups 1 and 2. Bilious reflux was revealed in nine. Diaphragmatic herniation was observed in 18 patients. The slow, trickling form of gastroesphageal reflux (GER) was demonstrated in 32 of 46 patients (69.5\%) (Table 1). In four other patients, the trickling reflux was not observed by ultrasound; however, one incompetent cardia was demonstrated with esophagoscopy in group 2 . The four patients in group 1 (no trickling reflux demonstrated) were evaluated as non-GERD; however, mycotic esophagitis was found in two of the esophagitis patients. In the 30 control patients (group 3), neither esophagitis nor trickling reflux was demonstrated (Table 2).

The basic therapy for patients with GERD was the administration of cisapride $5 \mathrm{mg}$ three times daily. Antacid treatment (1 $20 \mathrm{mg} /$ day omeprazole) was given to those who also suffered from hyperchlorhydria. The two mycotic esophagitis patients chewed and swallowed $3 \times 1$ tablets of nystatin (500,000 IU nystatin per tablet) for two weeks; the other two non-GERD esophagitis cases were treated by regular intake of sucralfat suspension (four to five times daily). 
The gastritis and ulcer patients (group 3) were treated on the basis of the chemistry of their gastric content (omeprazole 20 $\mathrm{mg}$ was prescribed for the hyperchlorhydric and $310 \mathrm{mg}$ domperidonum for the hypochlorhydric patients). All except two of the 46 GERD patients became symptom free in one week; the other two had to be sent for surgery (Nissen's fundoplication) for intractable reflux and Barrett's esophagus.

\section{DISCUSSION}

Ultrasound can display the regional anatomy of the abdominal organs and systems, and their motion patterns. The lower portion of the esophagus is situated para- and retrocardially, and reaches the stomach at a 35 to 45 angle, just below the diaphragm, at the level of the left hepatic lobe and the aorta. The transition between the spiral musculature of the LES and the longitudinal plicae of the stomach can also be distinguished. Ultrasonography of the esophagus was carried out first in fetuses and children to investigate anatomical disorders $(1,2)$. The esophagus, in adults, can be followed to the stomach as a characteristic parallel structure just behind the left lobe of the liver. When visualization is clear, it is easy to identify when aboral motion and reflux occur. The speed and direction of the reflux can also be seen. In a precise survey, diaphragmatic herniation can also be observed.

With the help of ultrasound, the events of swallowing and reflux can be studied at the LES area, the lower portion of the esophagus and the gastric cardia in adults. We unexpectedly observed a movement of the LES in some patients who suffered from endoscopically proven GERD. Unlike fast reflux and clearance observable also in healthy people, these patients displayed several episodes of a slow, trickling form of reflux that was not followed by immediate clearance. The esophagus discharged its content only after four to five slow reflux episodes, and only after about 0.5 to 2 mins. Holding a deep breath stopped trickling reflux in a number of cases; it is presumed that the hiatus esophagealis diaphragmae had narrowed and increased the pressure at the LES. Another possibility could be a narrowing of the esophageal sphincter in the elongated esophagus.

It is important that the phenomenon was observed in $69.5 \%$ of the examined GERD patients. The relatively high number may indicate the importance of this observation in GERD.

No instrumental examinations ( $\mathrm{pH}$ or manometric measurements) were used because we wanted to prevent any disruption of the normal state of the esophagus and the irritating effect of the devices ('Heisenberg's rule': in a system we also measure the effects of our tools). These methods may suffer from an intrinsic error because provocation of nausea and excitement is artificial.

Reviewing the recent literature available on GER, we did not find any data on using ultrasonography to analyze the events of GER. This method does not alter the real conditions, unlike $\mathrm{pH}$ and pressure measurements with their probes. Barium meal and scintigraphy (3) display only the gross events. Thus, ultrasound seems to provide reliable data

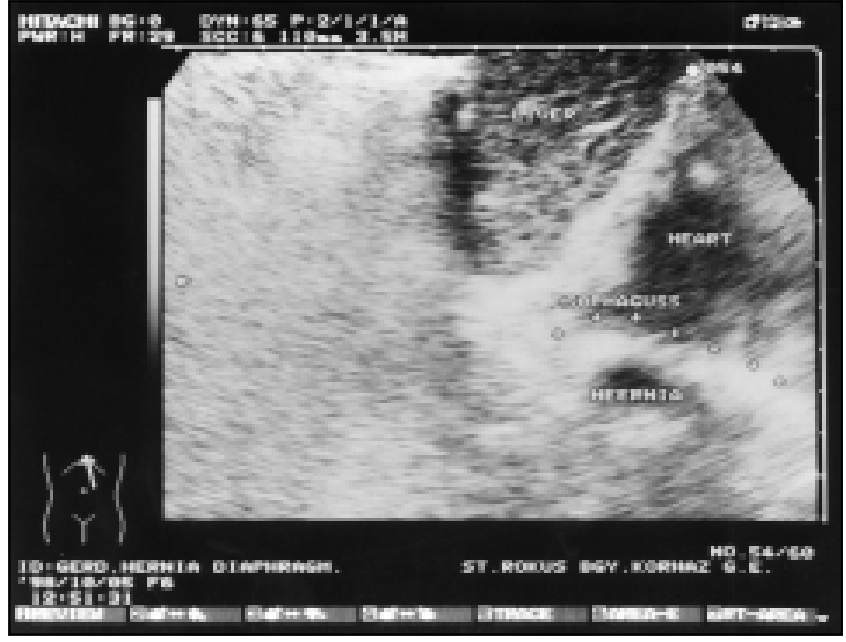

Figure 3) Longitudinal ultrasonogram of the lower portion of the esophagus and the cardia of the stomach. Cranial to the right, caudal to the left. Hernia diaphragmatica behind the esophagus

with details. Our observation, that there is also a slow type of reflux, corresponds to the results of Schoeman and Holloway $(4,5)$, who demonstrated the volume-dependency of secondary esophageal peristalsis under experimental condition, and the lower rate of peristalsis in GERD patients. This observation may also explain the surprising data of Barham et al (6), in that the severity of reflux disease is parallel to the higher number of reflux episodes and their longer duration, and it has an inverse relationship with the degree of LES relaxation in reflux periods. Less relaxation may result in a trickling reflux. Similar findings were noted by Pustorino et al (7). According to the $24 \mathrm{~h} \mathrm{pH}$ monitoring of Hendrix (8) and Bollschweiler et al (9), there is a high number of serious refluxes that do not correspond to the clinical and histological severity of GERD. There is also a high number of significantly serious refluxes that are of the fast form. This observation supports our theory that any period of fast refluxes followed by immediate clearance does not harm the esophageal mucosa as much as the same period spent under trickling reflux that is not followed by subsequent secondary clearance.

The frequent occurrence of insufficient esophageal clearance by Lin et al (10) describes what happens after barium meals, and fluoroscopic and scintigraphic assays of the esophageal residue in reflux patients without esophagitis versus reflux patients with esophagitis. Pustorino et al (7) found that the LES pressure is reduced significantly and that uncoordinated LES relaxation on swallowing is increased in patients with GERD. Uncoordinated LES relaxation helps the development of trickling reflux.

\section{CONCLUSIONS}

On the basis of these findings, it is presumed that the defending motor reflex (secondary peristalsis) generated by esophageal distension is undeveloped in slow, trickling reflux. Thus, the bicarbonate of the saliva and the esophageal secretum (11) cannot defend the esophageal mucosa. In 
GERD, the disorder of these mechanisms, the deterioration of sensory, tonic or both functions is presumed.

Because we observed this type of GER only in patients with GERD, it is presumed that this is a special form and that it may be characteristic of the disease. Although theoretically it may be secondary to pathological conditions of the LES, we think that it has a basic role in causing and maintaining the disease. It was observed only in patients with GERD, and it exposes the esophageal mucosa for a time sufficient to cause harm to it.

\section{REFERENCES}

1. Eftekhari F, Fornage BD, Mahon TG. Carcinoma of the cervicothoracic esophagus: sonographic findings and guided percutaneous needle biopsy. J Clin Ultrasound 1992;20:632-5.

2. Satoh S, Takashima T, Takeuchi M, Koyanagi T, Nakano H. Antenatal sonographic detection of the proximal esophageal segment: specific evidence for congenital esophageal atresia. J Clin Ultrasound 1995;23:419-23.
3. Singh S, Richter JE. Effects of a pH electrode across the lower esophageal sphincter. Dig Dis Sci 1992;37:667-72.

4. Schoeman MN, Holloway RH. Stimulation and characteristics of secondary oesophageal peristalsis in normal subjects. Gut 1994;35:152-8.

5. Schoeman MN, Holloway RH. Integrity and characteristics of secondary oesophageal peristalsis in patients with gastro-oesophageal reflux disease. Gut 1995;36:499-504.

6. Barham CP, Gotley DC, Mills A, Alderson D. Precipitating causes of acid reflux episodes in ambulant patients with gastroesophageal reflux disease. Gut 1995;36:505-10.

7. Pustorino S, Migliorato D, Ianni G, Martinez $P$, Guerrisi $O$, Federico G, Luzza G. [Changes in mechanical and functional processes of the lower esophageal sphincter in patients with reflux esophagitis]. Recenti Prog Med 1990;81:429-34.

8. Hendrix TR. pH monitoring: is it the gold standard for the detection of gastroesophageal reflux disease? Dysphagia 1993;8:122-4.

9. Bollschweiler E, Feussner H, Holscher AH, Siewert JR. pHmonitoring: the gold standard in detection of gastrointestinal reflux disease? Dysphagia 1993;8:118-21.

10. Lin S, Ke M, Xu J, Kahrilas PJ. Impaired esophageal emptying in reflux disease. Am J Gastroenterol 1994;89:1003-6.

11. Brown CM, Snowdon CF, Slee B, Sandle LN, Rees WD. Effect of topical oesophageal acidification on human salivary and oesophageal alkali secretion. Gut 1995;36:649-53. 


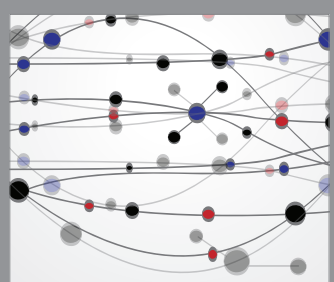

The Scientific World Journal
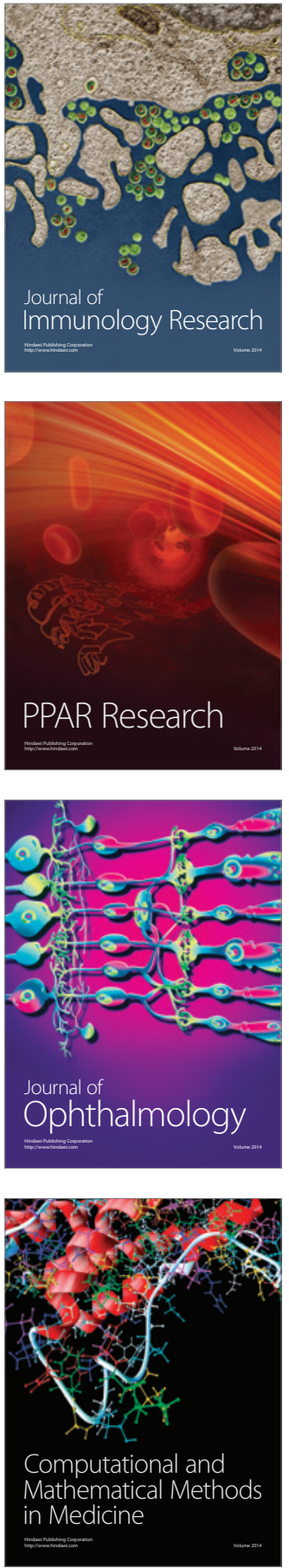

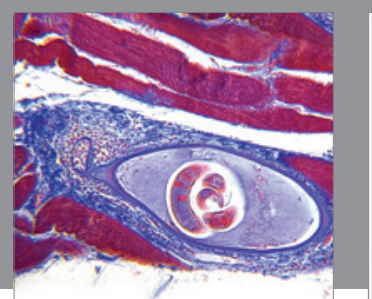

Gastroenterology Research and Practice

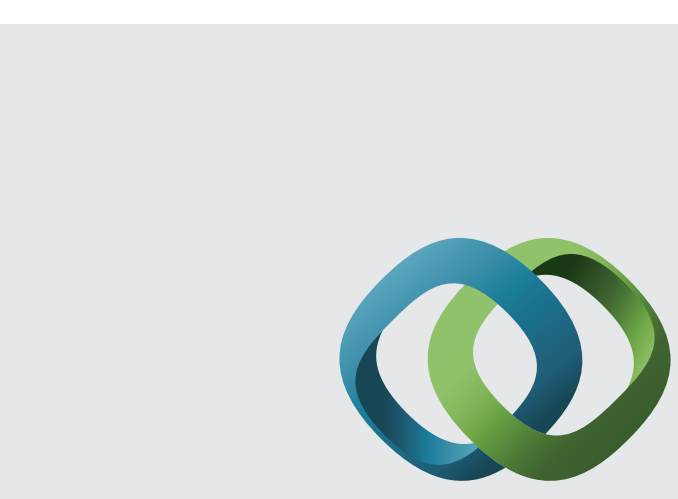

\section{Hindawi}

Submit your manuscripts at

http://www.hindawi.com
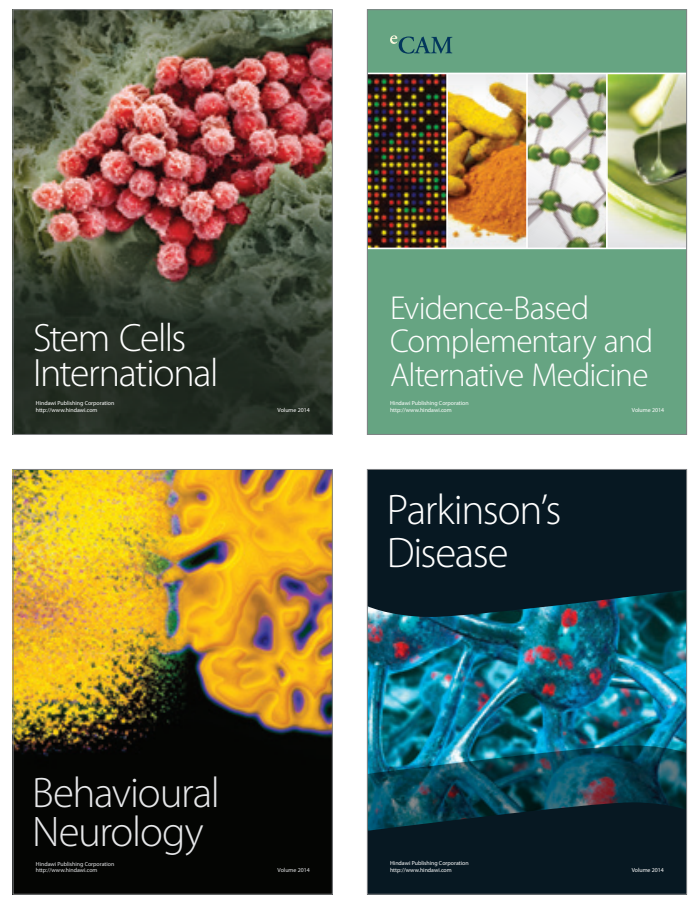
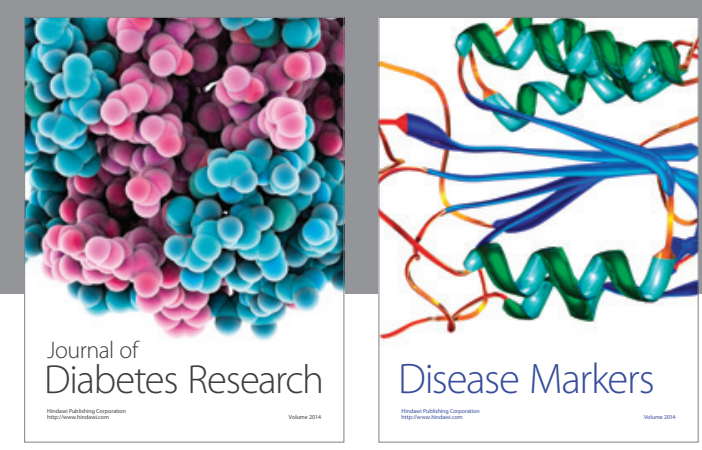

Disease Markers
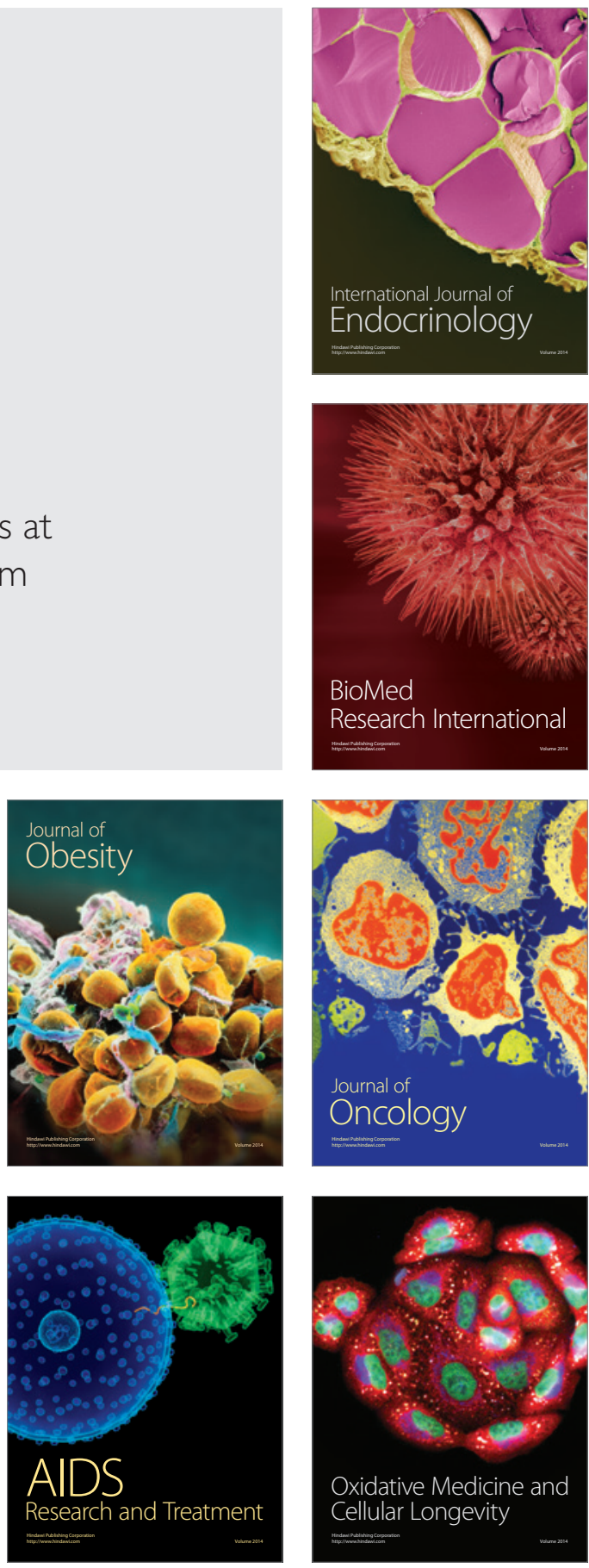